\title{
Green Organizational Identity and Environmental Commitment in Higher Education
}

\author{
Dr. Abdelghafour Al-Zawahreh \\ Associate Professor of management \\ The Hashemite University \\ Zarqa-JORDAN \\ Dr. Salah Hailat \\ Associate Professor of social studies \\ The Hashemite University \\ Zarqa-JORDAN \\ Dr. Mahmoud Al-Jaradat \\ Associate Professor \\ Educational Foundation and Administration \\ The Hashemite University \\ Zarqa-JORDAN \\ Dr. Omar Bataineh \\ Assistant Professor \\ Educational Foundation and Administration \\ The Hashemite University \\ Zarqa-JORDAN
}

\begin{abstract}
The present study is exploratory in nature with the aim of investigating the impact of green organizational identity on environmental commitment in one public university setting in Jordan. The sample of the study consisted of 177 academic participants whom were selected randomly. Results of the study indicated high levels of green organizational identity and environmental commitment in the university under investigation. Moreover, a positive and very strong relationship was found between green organizational identity and environmental commitment. Furthermore, results showed that green organizational identity alone predicted $31 \%$ of the shared variance in environmental commitment. However, demographic variables did not contribute to the explained variance. Finally, the study proposed a number of recommendations for professionals and practitioners.
\end{abstract}

Keywords: Green organizational identity, environmental commitment, higher education, and Jordan.

\section{Introduction}

Organizations worldwide are facing increased pressure from their stakeholders to protect the environment, adopt pro-environmental practices, and to improve sustainability-based performance (Endrikat, Guenther, \& Hoppe, 2014; Hong, Kwon, \& Roh, 2009; Jones, 2014; Pandey, Rupp, \& Thornton, 2013; Sarkis, Gonzalez-Torre, \& Adenso-Diaz, 2010). Based on that, organizations should adopt environmental management strategies as well as change their mindsets with regard to green opportunities and innovations (Chang \& Chen, 2013). In addition, this type of environmental commitment is necessary for organizations to obtain social support (Keogh \& Polonsky, 1998). Given the priority of environmental commitment, it is important to understand how it is sustained in organizations.

Over the last decade, environmental commitment has gained considerable attention in the literature due to its ability to direct individual behaviors to solve environmental and societal problems (Bingham, Mitchell, Bishop, \& Allen, 2013; Blome \& Paulra, 2013; Dwyer, 2007; Klein, Molloy, \& Brinsfield, 2012; Lawler, Thye, \& Yoon, 2009; Nesse, 2001; Ones \& Dilchert, 2012). 
Business environmental commitment has been found to influence sustainable performance of organizations (Tallon, 2008), especially when employees are concerned about the impact of their business on the environment (Gadenne, Kennedy, \& McKeiver, 2009). Further, environmental commitment is useful to encourage green initiatives and environmental strategies (Keogh \& Polonsky, 1998). Therefore, an organizational "corporate environmental performance is desirable, proper, or appropriate" (Bansal \& Clelland, 2004, p. 94).

Environmental commitment is defined as "an internal, obligation-based motivation" (Perez, Amichai-Hamburger, \& Shterental, 2009, p. 599). Cantor, Morrow, and Montabon (2012) defined environmental commitment as an "emotional attachment, identification, and involvement with environmental behaviors" (p. 36). Others have defined environmental commitment as an important organizations ethics that are geared toward green activities related to environmental protection (Chang, 2011; York, 2009).Environmental commitment is defined as the resources and efforts which an organization devotes in the environmental protection (Henriques \& Sadorsky, 1999). Environmental commitment refers to what an organization is actually doing or has done with regard to environmental activities (McAllister \& Studlar, 1999).

Based on the above definitions, it is obvious that environmental commitment generally reflects a mind-set, psychological state, and an internal disposition that gives behavioral direction toward a target (e.g., proenvironmental behaviors of individuals) in the workplace (Bingham et al., 2013; Klein et al., 2012; Lamm, TostiKharas, \& Williams, 2013; Meyer \& Herscovitch, 2001). Therefore, environmental commitment is a primary stakeholder that deserves the utmost attention (Driscoll \& Starik, 2004).

Environmental commitment may be influenced by several concepts, such as organizational identity. Organizational identity is among "the most popular topics in contemporary organizational studies" (Sveningsson \& Alvesson, 2003, p. 1163). Organizational identity has received extensive research attention that tries to identify how people perceive themselves as members of their organizations (Ashforth \& Mael, 1989; Nag, Corley, \& Gioia, 2007).

Organizational identity "refers to those core, distinctive, and enduring features unique to an institution" (Albert \& Whetten, 1985, p. 256) and represents "the shared beliefs of members about the central, enduring and distinctive characteristics of the organization" (Goldern-Biddle \& Rao, 1997, p. 594). Organizational identity refers to "members' understandings and claims about what is central, distinctive, and continuous over time about their organization" (Clark, Gioia, Ketchen, \& Thomas, 2010, p. 397). This means that organizational members have shared meanings about specific features that come from participation in the organization (Cornelissen, Haslam, \& Balmer, 2007). In other words, organizational identity is a distinct feature of any given organization that motivates actions of organizational members (Corley, Harquail, Pratt, Glynn, Fiol, \& Hatch, 2006).

Previous research suggests that organizational identity influences thinking and behavior of organizational members in areas related to classification of roles, reaction to problems, and actions taken in times of success and failure (Ashforth et al., 2008). Organizational identity can provide employees with a frame of reference (e.g., who am I? as an employee, and who are we? As an organization), which helps them to take actions related to self and organizational stakeholders (Ashforth, Harrison, \& Corley, 2008; Corley et al., 2006; DeConinck, 2011; Goldberg, 2003; Weick, 1995). Every organization needs an identity for their stakeholders to construct a sense of how it should act with other organizations and people (Albert, Ashforth, \& Dutton, 2000).

Organizational identity is dynamic and ongoing process that constantly changes according to contextual requirements to make organizations better (Gioia \& Patvardhan, 2012; Kourti, 2013 Pratt, 2012; Watson, 2008). Based on that, organizational members can alter their interpretations and form new conceptualizations that would reform organizational identity in face of environmental changes (Gioia \& Thomas, 1996). This, in turn, plays an important role for the success of organization (Sillince \& Brown, 2009). When environmental management becomes a strategic goal for the organization and part of its identity as a green organization, then organizational members are encouraged to contribute more to environmental commitment behaviors and actions (Sharma, 2000). This has led to the formation of green organizational identity, a new environmental management concept, which was defined as a shared interpretive system about environmental management and protection that members of an organization collectively build in order to provide meaning to their actions (Chen, 2011; Gioia, 1998). This concept has pushed environmental sustainability initiatives and green management practices to the forefront of organizational strategic agendas (Reinhardt, Stavins, \& Vietor, 2008). 
When concern for the environment becomes an integral component of organizational identity, environmental management and issues become harder to ignore and employees contribute on a discretionary basis toward environmental commitment (Smith \& O'Sullivan, 2012). The above discussion suggests that green organizational identity is positively related to and can have an impact on environmental commitment.

\section{Research Problem and Questions}

Environmental commitment represents a major social concern due to its capability to solve environmental issues and to contribute to sustainable performance of organizations. Previous research indicated that green organizational identity is among the utmost factors that can contribute to environmental commitment. However, there has been scant research which has focused on the relationship between green organizational identity and environmental commitment in Jordanian university system. Therefore, the primary purpose of this study was to achieve the following questions:

- What is the level of green organizational identity and environmental commitment as perceived by faculty members from one university setting in Jordan?

- What is the direction and strength of relationship between green organizational identity and environmental commitment as perceived by faculty members from one university setting in Jordan?

- What is the impact of green organizational identity beside demographic variables on environmental commitment as perceived by faculty members from one university setting in Jordan?

\section{Research Methodology}

\section{Study Participants}

The participants for this study consisted of a random sample of 230 faculty members employed by one public university in Jordan. Of those, 177 usable responses were retained with a $77 \%$ response rate. The sample description was 79 faculty members from science colleges and 98 from social science colleges. There were 33 lecturers, 81 assistant professors, 50 associate professors, and 13 professors. With regard to gender of participants, there were 131 males and 46 females. As far as years of work experience is concerned, 63 faculty members indicated less than five years of experience, 78 between five to ten years of experience, 18 between 11-15 years of experience, and 18 more than 15 years of experience.

\section{Instrumentation}

The instruments used to collect data in this study were the green organizational identity scale (GOIS) and the environmental commitment scale (ECS). Demographic information was also collected in this study such as gender, academic rank, academic discipline, and academic experience. The GOIS was developed by Milliken (1990) and validated by Gioia and Thomas (1996). On a later date, Chen (2011) adopted the organizational identity measure proposed by Gioia and Thomas (1996) and consulted the definition provided by Albert and Whetten (1985) to establish a novel concept named "green organizational identity" which is "as an interpretive scheme about environmental management and protection that members collectively construct in order to provide meaning to their behaviors" (Chen, 2011, p. 394). The items of the scale were tested with 138 respondents from the manufacturing industry in Taiwan and resulted in a reliability alpha of 0.77 . The six items of the scale were rated on a Likert response anchors ranging from 1 "strongly disagree" to 5 "strongly agree". To measure green organizational identity, the higher the score, the higher the green organizational identity is perceived to be.

The second part of the instrument is the environmental commitment scale (ECS) which is used to determine organizational members' commitment toward the environment. The ECS was developed by Raineri and Paille (2016) based on previous research (Allen \& Meyer, 1990; Herscovitch \& Meyer, 2002), which is composed of eight items. Items of the scale are rated on a Likert-response scale with 5 indicating "strongly agree" and 1 indicating "strongly disagree" were higher scores indicating higher levels of environmental commitment. The ECS yielded internal consistency estimate of 0.90 in previous research (Raineri \& Paille, 2016). A pilot group of 30 faculty members were instructed to determine the validity of both scales used in this study. Responses from the pilot group indicated that the items for both scales are a good representation for the constructs of the study and that the items are written clearly and the response scale used is appropriate.

\section{Data Collection and Analyses}

The data for this study was collected during the first semester of the academic years 2017/2018. 
The researchers explained to study participants the purpose of the study and guaranteed the confidentiality and voluntary nature of the study. Three weeks were the time needed to distribute and collect the instruments. To answer the first research question, means and standard deviations were used to determine the level of green organizational identity and environmental commitment. The cut off scores for determining their levels were as follow: low levels (below 2.49), medium levels (2.5-3.49), and high levels (above 3.5). Pearson correlation was used to answer the second research question with regard to the strength and direction of the association between green organizational identity and environmental commitment. Multiple regression analysis was used to answer for research question three and to determine the impact of green organizational identity (independent variable) on environmental commitment (dependent variable). The other variables (green organizational identity and participant demographics) were treated as independent variables.

\section{Results and Discussion}

The results regarding research question one which aimed to determine the level of green organizational identity and environmental commitment based on the perceptions of faculty members indicated the following: The overall mean value for the green organizational identity was $3.68(\mathrm{SD}=0.74)$. In the present study, there are indications that a high level of green organizational identity is present at the university setting under study. Moreover, the reliability coefficient for this measure was 0.92, implying that the scale is an appropriate measure of green organizational identity in this university setting (Robinson, Shaver, \& Wrightsman, 1991).

This result is consistent with previous research (Chang \& Chen, 2013; Chen, 2011), which indicated that organizational members under study having high levels of green organizational identity. It is obvious from the results of the study that faculty members under have detailed knowledge about the history of their university with respect to environmental traditions, cultures, management, and protection which gave them a sense of pride. Moreover, faculty members perceived their university to pay elevated attention to environmental management and protection initiatives and this was articulated by the presence of a well-developed environmental goals and missions. In turn, these practices have carved out a significant position for the university under study. This idea is supported by the notion that organization's unique characteristics related to environmental protection and management is what differentiates one organization from other organizations (Whetten, 2006). This should lead organizations to develop a unique organizational identity (Albert \& Whetten, 1985; DeConinck, 2011).

The overall mean value for the environmental commitment construct was $4.04(\mathrm{SD}=0.67)$ indicating high levels of environmental commitment. Furthermore, the reliability coefficient for this measure was 0.93, implying that the scale is an appropriate measure of environmental commitment in this university setting (Robinson, Shaver, \& Wrightsman, 1991). The results of the study also indicate that faculty members under study have high levels of environmental commitment. This result is consistent with previous research (Chang \& Chen, 2013; Raineri \& Paille, 2016). It is obvious from the results of the study that faculty members care about, have a sense of duty, personally attached, and support the environmental efforts and concerns of their university. Faculty members also value their university's environmental efforts and feel that environmental problems of their university are their own problems. Collier and Esteban (2007) emphasized the above notion that employees who share the environmental concerns of their organization are more likely to form pro-environmental behaviors.

The second research question aimed to determine the strength and association of the relationship between green organizational identity and environmental commitment based on faculty members' perceptions. Results of Pearson correlation coefficient of $0.56(\mathrm{p}=0.000)$ value indicated a positive and significant relationship between green organizational identity and environmental commitment using Davis' (1971) descriptors. These results show that faculty members with high levels of green organizational identity have a propensity to have high levels of environmental commitment.

The third research question aimed to determine the impact of green organizational identityon the environmental commitment of faculty members in one university setting in Jordan. Based on multiple regression analyses, as can be seen in table 1, the independent variables combined (green organizational identity, gender, academic rank, academic discipline, and academic experience) explained $32.7 \%$ of the common variance in the dependant variable (environmental commitment). To determine the unique effect for each independent variable regarding the percentage of variance explained in the dependent variable, hierarchical entry of the independent variables technique was utilized. As can be seen in table (2), green organizational identity was the only significant independent variable, which predicted $31.1 \%$ of the common variance in environmental commitment. 
These results are justified by the fact that when environmental issues become an essential part of organizational identity then environmental commitment in the form of management and protection is more difficult to be overlooked (Chen, 2011; Sharma, Pablo, \& Vredenburg, 1999).

Table (1)Strength of the Relationship between Overall Environmental Commitment and Independent Variables

\begin{tabular}{|c|c|c|c|c|}
\hline $\mathrm{R}$ & $\mathrm{R}^{2}$ & Std. Error & F Change & $p$ \\
\hline .572 & .327 & .55 & 16.63 & .000 \\
\hline
\end{tabular}

Table (2) The Unique Effect of Each Independent Variable on the Overall Environmental Commitment

\begin{tabular}{|l|l|l|l|l|l|l|l|}
\hline Variables & $\beta$ & $t$ & $\mathrm{R}$ & $\mathrm{R}^{2}$ & $\Delta \mathrm{R}^{2}$ & $\Delta \mathrm{F}$ & $p$ \\
\hline Green Organizational Identity & .558 & 8.896 & .558 & .311 & .311 & $79.133^{* *}$ & .000 \\
\hline Gender & $.101-$ & -1.612 & .567 & .322 & .010 & 2.598 & .109 \\
\hline Academic Rank & $.060-$ & -.941 & .570 & 0325 & .003 & .886 & .348 \\
\hline Academic Discipline & $.041-$ & -.614 & .571 & .326 & .001 & .377 & .540 \\
\hline Experience & .032 & .450 & .572 & .327 & .001 & .202 & .653 \\
\hline
\end{tabular}

It is important to note that the university under study has initiated a number of environmental-friendly projects related to efficient use of energy and resources such as solar power and water desalination among other environmental management and protection initiatives. Such projects have boosted the economic and financial resources for the university. In turn, it is becoming a standard practice and part of the university's mission and goals to pursue such environmental friendly projects leading to sustainable-healthy performance. These initiatives have instilled a sense of green identity among faculty members in this university as to the utility and importance of the environmental management and protection practices which gave them a behavioral direction and motivation toward pro-environmental behaviors (Corley et. al., 2006; Bingham et al., 2013). Employees' perceptions about the green identity of their organization affect their interpretations of environmental issues and their subsequent behaviors toward environmental commitment. This concern for the environment has become an integral component of the university's organizational identity contributing toward green initiatives and environmental commitment (Smith \& O’Sullivan, 2012; York, 2009).

The above findings and discussion may propose a number of recommendations for the field of study. Theoretically, it is recommended to conduct similar studies in Jordan with larger samples representing multiple universities. Further studies may also include building a theoretical model that incorporates sources and consequences for green organizational identity and environmental commitment. There are also practical recommendations for the field of study such as (a) establishing and emphasizing green organizational identity and environmental commitment for new and existing faculty members through training programs, orientation sessions, workshops, and seminars, (b) requiring faculty members to incorporate green practices into university courses and to demonstrate to their students the social and economic value as a result of green practices such as environmental commitment of their organization, (c) provide financial and social incentives to those organizational members that innovate green practices within the university setting that eventually lead to sustainable performance, and (d) establish on-campus environmental center to role model proper environmental management and protection initiatives to local, regional, and international businesses and universities and provide related training.

Finally, this research represents a cornerstone for universities in Jordan to begin to rethink their green practices and its impact on long-term social and economic performance. Universities with green practices can attract the attention of national, regional, and global organizations, which in turn influence the public attitudes. Such action can be used as a marketing strategy to attract partnerships from various sources and business entities.

\section{References}

Albert, S., Ashforth, B. E., \& Dutton, J. E. (2000). Organizational identity and identification: Charting new waters and building new bridges. Academy of Management Review, 25(1), 13-17.

Albert, S., \& Whetten, D. A. (1985). Organizational identity. Research in Organizational Behavior, 7, 263-295.

Allen, N. J., \& Meyer, J. P. (1990). The measurement and antecedents of affective, continuance and normative commitment to the organization. Journal of Occupational Psychology, 63(1), 1-18. 
Ashforth, B. E., Harrison, S. H., \& Corley, K. G. (2008). Identification in organizations: An examination of four fundamental questions. Journal of Management, 34, 325-374.

Ashforth, B. E., \& Mael, F. (1989). Social identity theory and the organization. Academy of Management Review, 14, $20-39$.

Bansal, P., \& Clelland, I. (2004). Talking trash: legitimacy, impression management, and unsystematic risk in the context of the natural environment. Academy of Management Journal, 47(1), 93-103.

Bingham, J. B., Mitchell, B. W., Bishop, D. G., \& Allen, N. J. (2013). Working for a higher purpose: A theoretical framework for commitment to organization-sponsored causes. Human Resource Management Review, 23(2), 174189.

Blome, C., \& Paulraj, A. (2013). Ethical climate and purchasing social responsibility: A benevolence focus. Journal of Business Ethics, 116(3), 567-585.

Cantor, D. E., Morrow, P. C., \& Montabon, F. (2012). Engagement in environmental behaviors among supply chain management employees: An organizational support theoretical perspective. Journal of Supply Chain Management, 48(3), 33-51.

Chang, C. H. (2011). The influence of business environmental commitment on competitive advantage: The mediation role of green innovation. Journal of Business Ethics, 104(3), 361-370.

Chang, C., \& Chen, Y. S. (2013). The determinants of green intellectual capital. Management Decision, 50(1), 74-94.

Chen, Y. S. (2011). Green organizational identity: Sources and consequence. Management Decision, 49(3), $384-404$.

Clark, S. M., Gioia, D. A., Ketchen, D. J., \& Thomas, J. B. (2010). Transitional identity as a facilitator of organizational identity change during a merger. Administrative Science Quarterly, 55(3), 397-438.

Collier, J., \& Esteban, R. (2007). Corporate social responsibility and employee commitment. Business Ethics: A European review, 16(1), 19-33.

Corley, K. G., Harquail, C. V., Pratt, M. G., Glynn, M. A., Fiol, M. C., \& Hatch, M. J. (2006). Guiding organizational identity through aged adolescence. Journal of Management Inquiry, 15(2), 85-99.

Cornelissen, J. P., Haslam, S. A., \& Balmer, J. M. (2007). Social identity, organizational identity and corporate identity: Towards an integrated understanding of processes, patterning and products. British Journal of Management, 18, 116.

Davis, J. A. (1971). Elementary survey analysis. Englewood Cliff, NJ: Prentice Hall.

DeConnick, J. (2011). The effects of leader-member exchange and organizational identification on performance and turnover among salespeople. Journal of Personal Selling and Sales Management, 31(1), 21-34.

Driscoll, C., \& Starik, M. (2004). The primordial stakeholder: Advancing the conceptual consideration of stakeholder status for the natural environment. Journal of Business Ethics, 49(1), 55-73.

Dwyer, R. J. (2007). Utilizing simple rules to enhance performance measurement, competitiveness and accountability growth. Business Strategy Series, 8(1), 72-7.

Endrikat, J., Guenther, E., \& Hoppe, H. (2014). Making sense of conflicting empirical findings: A meta-analytic review of the relationship between corporate environmental and financial performance. European Management Journal, 32, $735-751$.

Gadenne, D. L., Kennedy, J., \& McKeiver, C. (2009). An empirical study of environmental awareness and practices in SMEs. Journal of Business Ethics, 84(1), 45-63.

Gioia, D. A. (1998). From individual to organizational identity. In identity in organizations building theory through, conversations 2. Edited by David A. Whetten and Paul C. Godfrey. Thousand Oaks: Sage Publications.

Gioia, D. A., \& Patvardhan, S. (2012). Identity as process and flow. In Schultz, M., Maguire, S., Langley, A. and Tsoukas, H. (Eds), constructing identity in and around organizations. Oxford University Press, Oxford.

Gioia, D. A., \& Thomas, J. B. (1996). Identity, image and issue interpretation: Sense-making during strategic change in academia. Administrative Science Quarterly, 41, 370-403.

Goldberg, C. B. (2003). Applicant reactions to the employment interview: A look at demographic similarity and social identity theory. Journal of Business Research, 56(8), 561-71.

Goldern-Biddle, K., \& Rao, H. (1997). Breaches in the boardroom: Organizational identity and conflicts of commitment in a nonprofit organization. Organizational Science, 8(6), 593-611.

Herscovitch, L., \& Meyer, J. P. (2002). Commitment to organizational change: Extension of a three-component model. Journal of Applied Psychology, 87(3), 474-487.

Hong, P., Kwon, H., \& Roh, J. J. (2009). Implement of strategic green orientation in supply chain: An empirical study of manufacturing firms. European Journal of Innovation, 12(4), 512-532.

Jones, M. J. (2014). Accounting for biodiversity. London: Routledge.

Keogh, P. D., \& Polonsky, M. J. (1998). Environmental commitment: A basis for environmental entrepreneurship. Journal of Organizational Change Management, 11(1), 38-49.

Klein, H. J., Molloy, J. C., \& Brinsfield, C. T. (2012). Reconceptualizing workplace commitment to redress a stretched construct: Revisiting assumptions and removing confounds. Academy of Management Review, 37(1), $130-151$. 
Kourti, I. (2013). Between planned and emergent collaboration: Boundary activation and identity development in the psychosocial space of a Greek educational partnership. $\mathrm{PhD}$ thesis, submitted to the London School of Economics, London.

Lamm, E., Tosti-Kharas, J., \& Williams, E. G. (2013). Read this article, but don't print it: Organizational citizenship behavior toward the environment. Group \& Organization Management, 38(2), 163-197.

Lawler, E. J., Thye, S. R., \& Yoon, J. (2009). Social commitments in a depersonalized world. New York: Russell Sage Foundation.

McAllister, I., \& Studlar, D. T. (1999). Green versus brown: Explaining environmental commitment in Australia. Social Science Quarterly, 80(4), 775-792.

Meyer, J. P., \& Herscovitch, L. (2001). Commitment in the workplace: Toward a general model. Human Resource Management Review, 11(3), 299-326.

Milliken, F. J. (1990). Perceiving and interpreting environmental change: An examination of college administrators' interpretation of changing demographics. Academy of Management Journal, 33, 42-63.

Nag, R., Corley, K. G., \& Gioia, D. A. (2007). The intersection of organizational identity, knowledge, and practice: Attempting strategic change via knowledge crafting. Academy of Management Journal, 50(4), 821-847.

Nesse, R. M. (2001). Evolution and the capacity for commitment (Vol. 3). New York: Russell Sage Foundation.

Ones, D. S., \& Dilchert, S. (2012). Employee green behaviors. In S. E. Jackson, D. S. Ones, \& S. Dilchert (Eds.), Managing human resources for environmental sustainability (pp. 85-116). San Francisco: Jossey-Bass.

Pandey, N., Rupp, D. E., \& Thornton, M. A. (2013). The morality of corporate environmental sustainability: A psychological and philosophical perspective. In A. H. Huffman \& S. R. Klein (Eds.), Green organizations: Driving change with IO psychology (pp. 69-92). New York: Routledge.

Perez, O., Amichai-Hamburger, Y., \& Shterental, T. (2009). The dynamic of corporate self-regulation: ISO 14001, environmental commitment, and organizational citizenship behavior. Law \& Society Review, 43(3), 593-630.

Pratt, M. G. (2012). Rethinking identity construction processes in organizations: Three questions to consider, In Schultz, M., Maguire, S., Langley, A. and Tsoukas, H. (Eds), Constructing Identity in and Around Organizations, Oxford University Press, Oxford,pp. 21-49.

Raineri, N., \& Paille, P. (2016). Linking corporate policy and supervisory support with environmental citizenship bBehaviors: The role of employee environmental beliefs and commitment. Journal of Business Ethics, 137, 129148.

Reinhardt, F. L., Stavins, R. N., \& Vietor, R. (2008). Corporate social responsibility through an economic lens. Kennedy School of Government, Harvard University, Cambridge, MA.

Robinson, J. P., Shaver, P. R., \& Wrightsman, L. S. (1991) Measures of Personality and Attitudes, Academic Press: San Diego.

Sarkis, J., Gonzalez-Torre, P., \& Adenso-Diaz, B. (2010). Stakeholder pressure and the adoption of environmental practices: The mediating effect of training. Journal of Operations Management, 28(2), 163-176.

Sharma, S. (2000). Managerial interpretations and organizational context as predictors of corporate choice of environmental strategy. Academy of Management Journal, 43(4), 681-697.

Sharma, S., Pablo, A., \& Vredenburg, H. (1999). Corporate environmental responsiveness strategies: The importance of issue interpretation and organizational context. Journal of Applied Behavioral Science, 35(1), 87-108.

Sillince, J. A., \& Brown, A. D., (2009). Multiple organizational identities and legitimacy: The rhetoric of police websites. Human Relations, 62, 1829-1856.

Smith, A. M., \& O'Sullivan, T. (2012). Environmentally responsible behavior in the workplace: An internal social marketing approach. Journal of Marketing Management, 28(3-4), 469-493.

Sveningsson, S., \& Alvesson, M. (2003). Managing managerial identities: Organizational fragmentation, discourse and identity struggle. Human Relations, 56(10), 1163-1193.

Tallon, P. P. (2008). Inside the adaptive enterprise: An information technology capabilities perspective on business process agility. Information Technology and Management, 9(1), 21-36.

Watson, T. J. (2008). Managing identity: Identity work, personal predicaments and structural circumstances. Organization, 15(1), 121-143.

Weick, K. E. (1995). Sense-making in organizations. Thousand Oaks, CA: Sage.

York, J. G. (2009). Pragmatic sustainability: Translating environmental ethics into competitive advantage. Journal of Business Ethics, 85(1), 97-109.

Whetten, D. A. (2006). Albert and Whetten revisited: Strengthening the concept of organizational identity. Journal of Management Inquiry, 15, 219-234. 